US Army Corps

of Engineers $s_{\circledast}$

Engineer Research and

Development Center

\title{
Unit Hydrograph Peaking Analysis for Goose Creek Watershed in Virginia: A Case Study
}

Nawa Raj Pradhan and Drew Loney

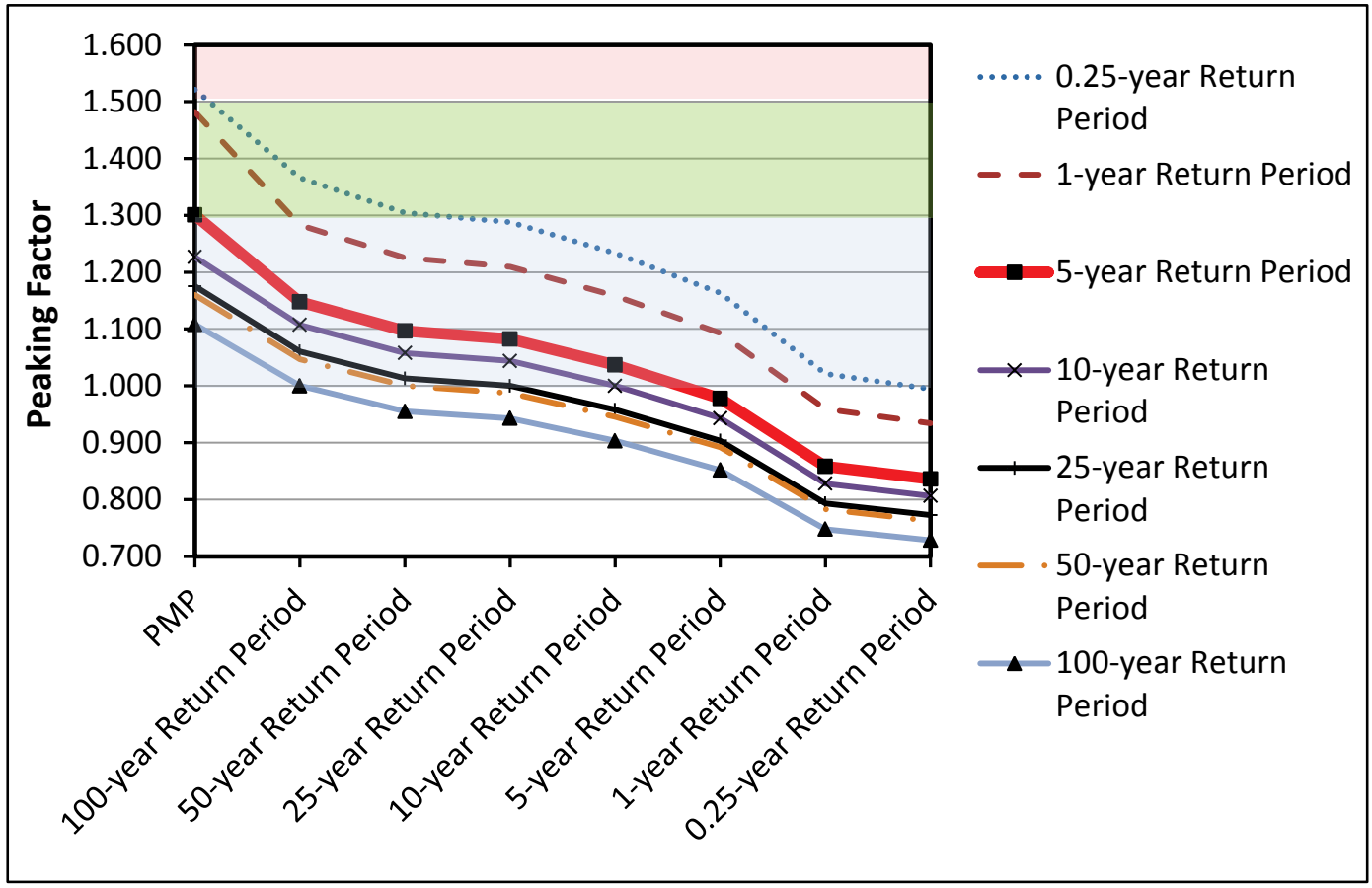


The U.S. Army Engineer Research and Development Center (ERDC) solves the nation's toughest engineering and environmental challenges. ERDC develops innovative solutions in civil and military engineering, geospatial sciences, water resources, and environmental sciences for the Army, the Department of Defense, civilian agencies, and our nation's public good. Find out more at www.erdc.usace.army.mil.

To search for other technical reports published by ERDC, visit the ERDC online library at http://acwc.sdp.sirsi.net/client/default. 


\section{Unit Hydrograph Peaking Analysis for Goose Creek Watershed in Virginia: A Case Study}

Nawa Raj Pradhan and Drew Loney

Coastal and Hydraulics Laboratory

US Army Engineer Research and Development Center

3909 Halls Ferry Road

Vicksburg MS 39180-6199

Final report

Approved for public release; distribution is unlimited.

Prepared for U.S. Army Corps of Engineers

Washington, DC 20314-1000

Under Project No. 52L3J9, "Unit Hydrograph Peaking Analysis for Dam Safety” 


\section{Abstract}

Existing U.S. Army Corps of Engineers (USACE) policy suggests unit hydrograph peaking factor (UHPF), the ratio of an observed event unit hydrograph peak to the modeled one for a catchment, ranges between 1.25 and 1.50 to ensure dam safety. It is pertinent to investigate the impact of extreme flood events on the validity of this range through physically based rainfall-runoff models not available during the planning and design of most USACE dams. The UHPF range was analyzed by deploying the Gridded Surface Subsurface Hydrologic Analysis model in the Goose Creek, VA, watershed to develop a peaking factor relationship with excess rainfall for National Oceanic and Atmospheric Administration rainfall depths across various return-period events as well as the National Weather Service probable maximum precipitation event. The effect of statistical uncertainty on UHPF at Goose Creek was determined by applying the 5\% and 95\% confidence interval precipitation depths to the watershed in addition to the $50 \%$ value. This study concluded that a design event with a return period greater than 5-year is required for the unit hydrograph to ensure dam safety. Goose Creek unit hydrograph was designed from 25-year return period rainfall and therefore ensures dam safety given the current UHPF guidance.

DISCLAIMER: The contents of this report are not to be used for advertising, publication, or promotional purposes. Citation of trade names does not constitute an official endorsement or approval of the use of such commercial products. All product names and trademarks cited are the property of their respective owners. The findings of this report are not to be construed as an official Department of the Army position unless so designated by other authorized documents. 


\section{Contents}

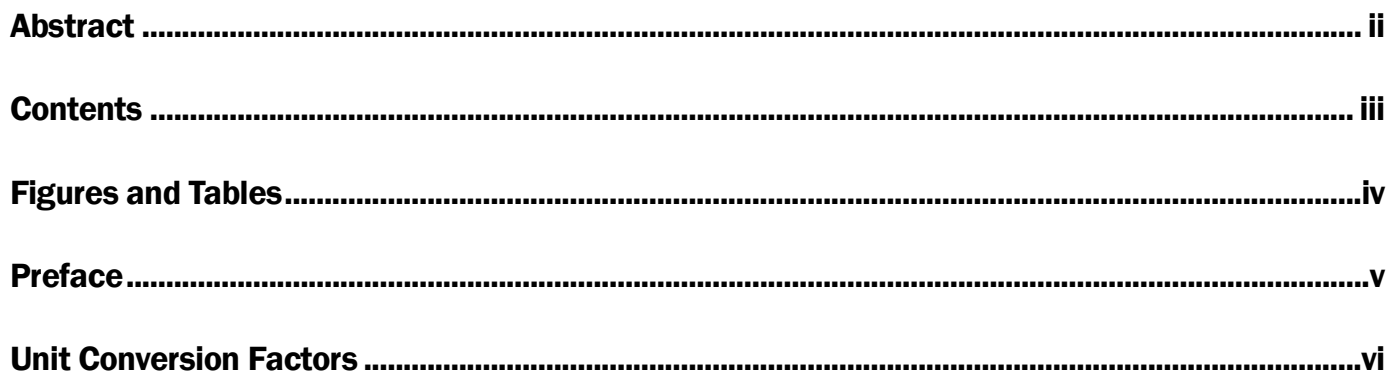

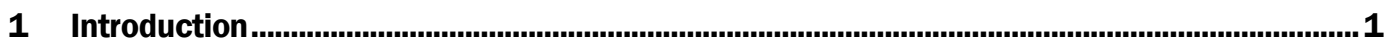

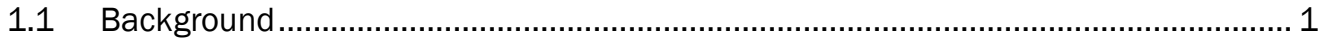

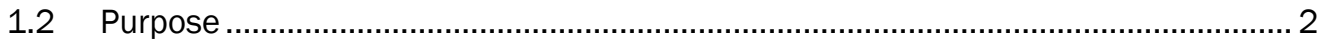

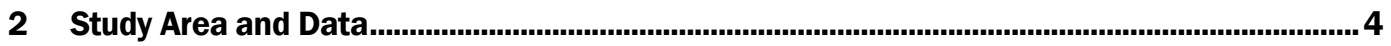

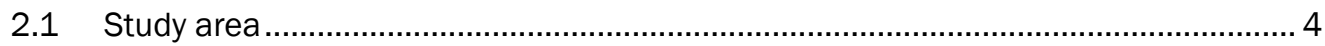

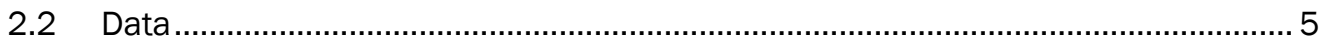

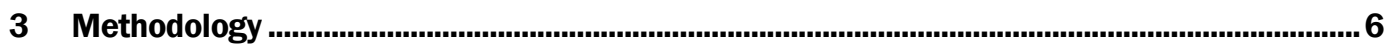

3.1 Utilizing historic discharge and rainfall data to derive a unit hydrograph (UH)............ 6

3.2 Utilizing GSSHA to perform two-dimensional (2D) watershed modeling to

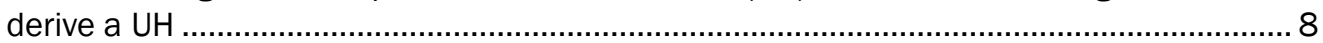

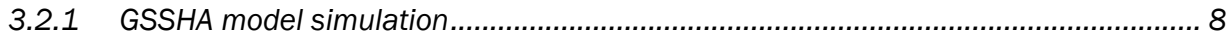

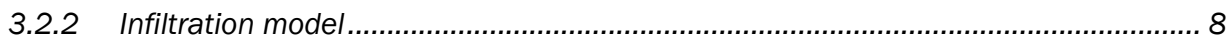

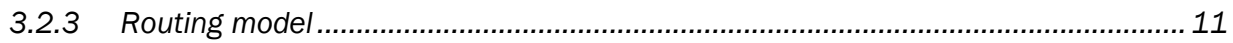

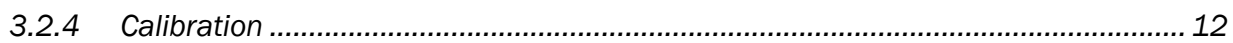

4 Results and Discussion .............................................................................................................13

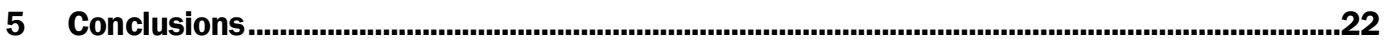

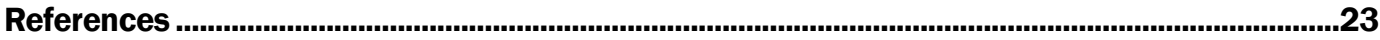

Report Documentation Page 


\section{Figures and Tables}

\section{Figures}

Figure 1. Goose Creek watershed (in Loudoun County of Virginia).................................................... 5

Figure 2. Deriving a UH for the Goose Creek watershed. ...................................................................

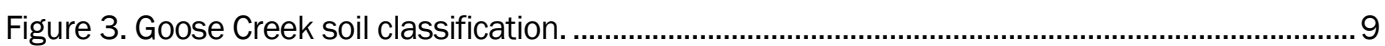

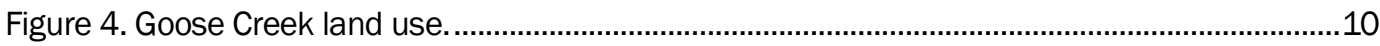

Figure 5. Goose Creek catchment GSSHA calibration (Nash-Sutcliffe Efficiency was 90\%).............12

Figure 6. NOAA Atlas 14; $6 \mathrm{hr}$ return period precipitation event temporal distribution estimation in the study area.................................................................................................................14

Figure 7. NOAA 50th percentile return period discharge from GSSHA simulations...........................14

Figure 8. NOAA 50th percentile return period UH from GSSHA simulations. ....................................15

Figure 9. Peaking factor sensitivity analysis chart.........................................................................17

Figure 10. Peaking factor and effective rainfall relationship. ……................................................18

Figure 11. Peaking factor as a function of return period and data processing uncertainty interval for the precipitation depths specified by NOAA Atlas 14 that were applied to the hydrologic model. The black line gives the 50th percentile peaking factor with lower and upper bars giving the 5th and 95th percentiles, respectively.

\section{Tables}

Table 1. Soil properties and infiltration parameters........................................................................

Table 2. Land use type and overland flow hydraulic roughness.....................................................11

Table 3. Derivation of the peaking factor in terms of GSSHA-simulated NOAA 50th percentile 0.25-year return period to 100-year return period in the Goose Creek Catchment.

Table 4. Equations of fit for the peaking factor analysis in Figure 11 for the considered data analysis confidence intervals.

Table 5. Return period for the PMP and maximum accepted peaking factor as calculated by inverting the functions fit the peaking factor/return period relationship. The form of each function is given in Table 4. 


\section{Preface}

This study was conducted for the Risk Management Center, U.S. Army Corps of Engineers, under the Project "Unit Hydrograph Peaking Analysis for Dam Safety.” The technical monitors were Mr. David Margo (CEIWRRMC) and Dr. Chandra Pathak (CECW-CE).

The work was performed by the Hydrologic Systems Branch (HF-H), Flood and Storm Protection Division (HF), U.S. Army Engineer Research and Development Center (ERDC), Coastal and Hydraulics Laboratory (CHL). At the time of publication of this report, Dr. Pearce Cheng was Branch Chief, CEERD-HF-H; Dr. Cary Talbot was Chief, CEERD-HF. Mr. Jeffrey R. Eckstein was the Deputy Director of ERDC-CHL, and the Director was Mr. José E. Sánchez.

COL Bryan S. Green was the Commander of ERDC, and the Director was Dr. David W. Pittman. 


\section{Unit Conversion Factors}

\begin{tabular}{|c|c|c|}
\hline Multiply & By & To Obtain \\
\hline acres & $4,046.873$ & square meters \\
\hline acre-feet & $1,233.5$ & cubic meters \\
\hline centistokes & $1.0 \mathrm{E}-06$ & square meters per second \\
\hline cubic feet & 0.02831685 & cubic meters \\
\hline cubic inches & 1.6387064 E-05 & cubic meters \\
\hline cubic yards & 0.7645549 & cubic meters \\
\hline degrees Fahrenheit & $(\mathrm{F}-32) / 1.8$ & degrees Celsius \\
\hline fathoms & 1.8288 & meters \\
\hline feet & 0.3048 & meters \\
\hline gallons (U.S. liquid) & $3.785412 \mathrm{E}-03$ & cubic meters \\
\hline hectares & $1.0 \mathrm{E}+04$ & square meters \\
\hline inches & 0.0254 & meters \\
\hline knots & 0.5144444 & meters per second \\
\hline microns & $1.0 \mathrm{E}-06$ & meters \\
\hline miles (nautical) & 1,852 & meters \\
\hline miles (U.S. statute) & $1,609.347$ & meters \\
\hline miles per hour & 0.44704 & meters per second \\
\hline mils & 0.0254 & millimeters \\
\hline ounces (U.S. fluid) & $2.957353 \mathrm{E}-05$ & cubic meters \\
\hline pints (U.S. liquid) & 4.73176 E-04 & cubic meters \\
\hline quarts (U.S. liquid) & $9.463529 \mathrm{E}-04$ & cubic meters \\
\hline square feet & 0.09290304 & square meters \\
\hline square inches & 6.4516 E-04 & square meters \\
\hline square miles & $2.589998 \mathrm{E}+06$ & square meters \\
\hline square yards & 0.8361274 & square meters \\
\hline yards & 0.9144 & meters \\
\hline
\end{tabular}




\section{Introduction}

\subsection{Background}

The U.S. Army Corps of Engineers (USACE) policy contained in ER 11108-2 (FR) (USACE 1991) requires that dams "designed, constructed, or operated by the USACE will not create a threat of loss of life or inordinate property damage." For a dam to be considered "hydrologically adequate" and in compliance with the USACE policy, an appropriate embankment, spillway, and regulating outlet, if necessary, must be designed to safely pass an Inflow Design Flood with adequate freeboard. USACE engineering practice utilizes extreme flood events to evaluate and manage flood risk at most dams. Extreme flood events are those events defined by large magnitudes and long return periods. However, it is unclear whether the simplifications employed for selecting design extreme flood events has led to over- or under-estimations of the watershed response and in turn, overor under-estimations of the required dam size. It is thus pertinent to investigate the impact of extreme flood events through the use of physically based rainfall-runoff models that were not available during the design and construction of most USACE dams to improve dam safety estimates.

In the past, the most common rainfall-runoff models used within the USACE for dam construction assumed both an initial and constant water loss to generate excess precipitation. The unit hydrograph theory, the most frequently used of these methods, transforms excess precipitation to a point runoff hydrograph. According to Sherman (1932), who originally proposed the unit hydrograph (UH) concept, the UH of a watershed is the outflow resulting from one unit of direct runoff generated uniformly over the drainage area at a uniform rainfall rate during a specified period of rainfall duration. This implies that the ordinates of any hydrograph resulting from a quantity of runoff-producing rainfall of unit duration would be equal to corresponding ordinates of a UH for the same areal distribution of rainfall, multiplied by the ratio of rainfall excess values. For the past 50 years, the USACE practice has been to increase the peak of a $\mathrm{UH}$ linearly, in relation to the observed rainfall, by $25 \%$ to $50 \%$ when the observed rainfall excess is significantly greater than the modeled rainfall excess used to calibrate the UH (USACE 1991). This multiplicative factor is typically referred to as the unit hydrograph peaking factor (UHPF). 
Natural variability of environmental systems often results in linear transfer functions (Childs 1958; Minshall 1960; Ding 1974; Kokkonen et al. 2004), as assumed in UH theory, to poorly characterize the range of possible outcomes from the same initial state. Linear transfer functions can be invalid due to multiple factors including differences in the varying antecedent initial conditions such as soil moisture (Pradhan et al. 2012; Hendrickx et al. 2016); runoff generation processes like infiltration excess (Downer and Ogden 2004); saturation excess (Pradhan and Ogden 2010); and hydro-geomorphology, urbanization, and land use change (Ogden et al. 2011). In most extreme flood investigations, the UHPF is rarely analyzed thoroughly in the context of natural watershed variability. Variability ultimately manifests as uncertainty in the relationship between precipitation and flood likelihood. A thorough analysis method relating hydrologic variables to the UHPF is essential to remove the assumption of linear behavior imposed by commonly employed empirical modeling methods. The analysis should also consider and quantify the aforementioned uncertainty to provide confidence information to decision makers.

Physically based hydrologic modeling is capable of testing the linearity and non-linearity of the watershed response (Szilagyi 2007). The Gridded Surface/Subsurface Hydrologic Analysis (GSSHA) model is a distributedparameter, physically based numerical model that has been used by the USACE in engineering hydrology (Downer et al. 2016); erosion (Downer et al. 2014); contaminant/nutrient fate and transport (Pradhan et al. 2014); as well as storm surge studies (Massey et al. 2013). Deploying a physically based hydrologic model will account for nonlinear watershed hydrological properties (Szilagyi 2007) as well as assist in developing a methodology to analyze/improve the estimation of peaking factor (USACE 1991) and rainfall excess relationships in different climatic regions of continental United States (Wolock et al. 2004).

\subsection{Purpose}

Existing USACE policy suggests UHPFs between 1.25 (125\%) and 1.50 (150\%). In other words, although a UH peak is assumed to increase linearly with the increase in the intensity of a precipitation event, the increment would not exceed 1.5 times the designed unit peak. The purpose of this study is to analyze the validity of this UHPF range of the Goose Creek watershed in Virginia via deploying the GSSHA model, a physically based hydrologic model that is capable of determining complex watershed behavior. Goose Creek watershed was selected because of the availability 
of existing baseline data from previous studies. This study also investigated the magnitude of a rainfall event associated with a 1.25 or 1.5 UHPF and developed a peaking factor relationship with excess rainfall in the study area.

This study is intended to serve as an example for deploying physically based hydrological models to analyze the $\mathrm{UH}$ and the peaking factor on other watersheds. If the $\mathrm{UH}$ and the peaking factor analyses for watersheds representing different climatic regions of continental United States are conducted in the same manner, one would develop a regionalized peaking factor relationship with excess rainfall, which potentially could be utilized to evaluate and improve, if needed, the safety of existing dams. 


\section{Study Area and Data}

\subsection{Study area}

USACE, Baltimore District (NAB) (1963), provides details on the derivation of standard UH in the Goose Creek watershed in Loudoun County, VA (Latitude: 39.019; Longitude: 77.577; Area: 339 square miles [miles $\left.\left.{ }^{2}\right]\right)$. The objectives of this 1963 study were the following:

- to collect a maximum of available information on $\mathrm{UH}$ methods and $\mathrm{UH}$ data

- to provide standardized methods, terminology, and forms for the presentation of UHs

- to present the accumulated data and information in a form useful to hydrologists.

Goose Creek watershed, shown in Figure 1, was selected as the study area for this pilot study of UHPF using the GSSHA model. The principal reason for selecting this watershed is that the watershed study by USACE (1963) provides baseline information on the UH data along with the standard practice in deriving the UH. The study area is located in the eastern United States, bounded by the Potomac River and Maryland on the northeast. The Goose Creek drains eastward into the Potomac River. The climate of Virginia is diverse and varies from warm and temperate in the eastern coastal areas, which have temperatures moderated by the Atlantic Ocean, to the cooler continental climate of the mountainous counties in the north and west (Sanford et al. 2011). The mean annual temperature is between 54 and $55^{\circ} \mathrm{F}$. The rainfall pattern varies across Virginia and is affected by topography in the north and west and by the presence of tropical moisture systems in the south and east. The mean annual precipitation in the study area is 42 inches. Temperature and rainfall are adequate to support a substantial agriculture industry, with crop and pasture lands evenly scattered between forests of mixed deciduous and evergreen trees across most of Virginia including the watershed (Sanford et al. 2011). 
Figure 1. Goose Creek watershed (in Loudoun County of Virginia).

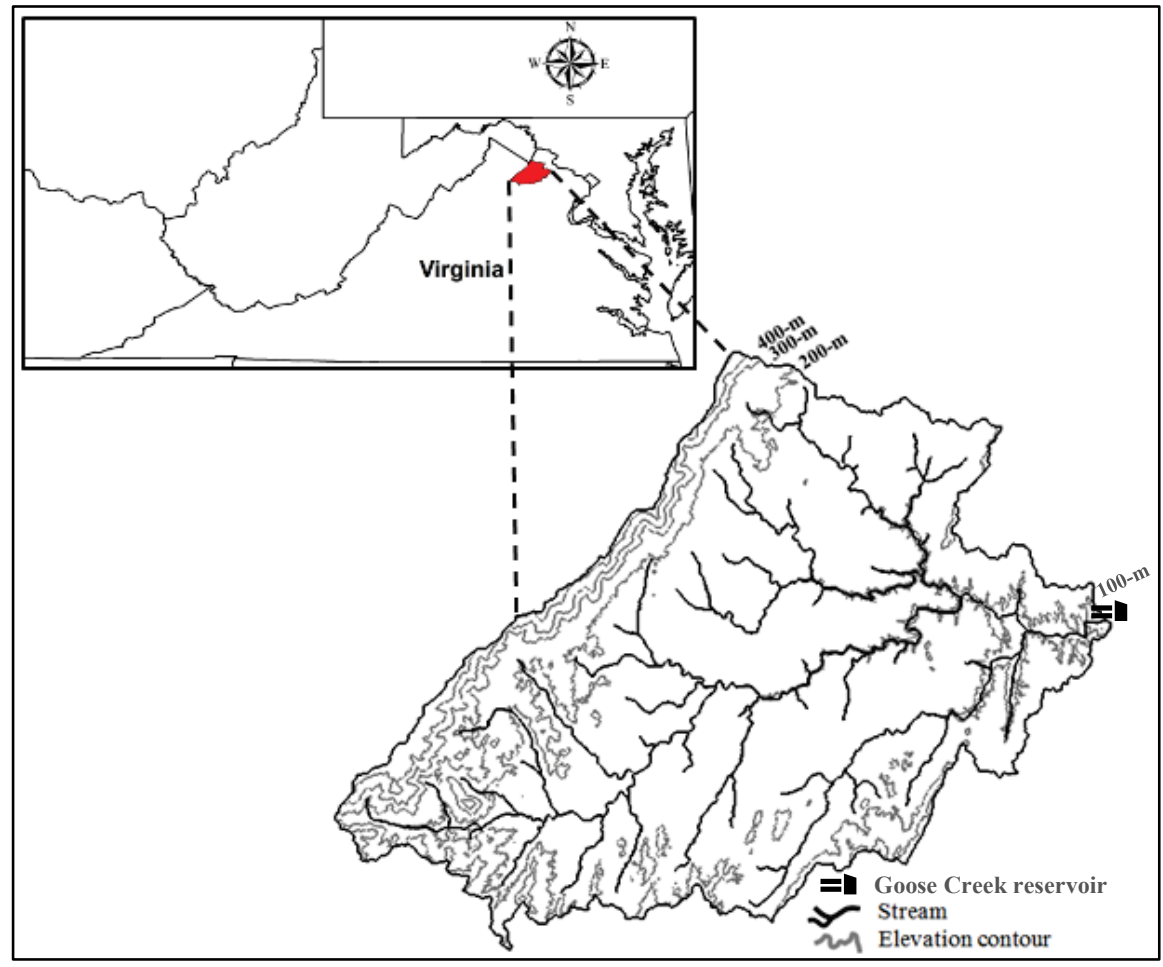

\subsection{Data}

The hourly precipitation data was obtained from Dulles International Airport in Dulles, VA (ID No. Coop - 448903). The discharge data at the outlet in Figure 1 were from U.S. Geological Survey station No. 1644000. Land use data was obtained from the National Land Cover Database (http://www.mrlc.gov/finddata.php). The soil data were obtained from the Natural Resources Conservation Service, Soil Survey Geographic Database (http://www.nrcs.usda.gov/wps/portal/nrcs/detail/soils/survey/geo/?cid=nrcs142p2_053631). The probable maximum precipitation (PMP) estimates was obtained from the Hydrometeorological Report No. 51 (USDoC 1978). Historical precipitation for Goose Creek is well characterized by the Precipitation Frequency Atlas 14, Volume 2, of the National Oceanic and Atmospheric Administration (NOAA). The Precipitation Frequency Atlas is the standard source of historical extreme precipitation information available in the continental United States. The return period precipitation was estimated from the NOAA Frequency Atlas 14 (http://hdsc.nws.noaa.gov/hdsc/pfds/). 


\section{Methodology}

Two different methods were used to derive UHs for the Goose Creek watershed:

1. Utilizing historic discharge and rainfall data

2. Utilizing GSSHA to perform two-dimensional (2D) watershed modeling to derive a UH from the return period events and the PMP event.

\subsection{Utilizing historic discharge and rainfall data to derive a unit hydrograph (UH)}

As per UH theory, the following steps were taken to derive a UH from the observed discharge:

1. Separate the base flow from the observed streamflow hydrograph to obtain the Direct Runoff Hydrograph QDRH. The steps for base flow separation are as follows:

a. Identify when direct runoff begins (i.e., end of the base flow-only period).

b. Estimate the duration of the direct runoff period $N$ using the empirical relationship below:

$$
N=A^{0.2}
$$

where $N$ is in days; $A$ is the basin area in square miles (Linsley et al. 1975).

2. Draw a line connecting the start and end of the time interval for the direct runoff. This line separates the direct runoff hydrograph from base flow hydrograph. Then, compute the volume of Direct Runoff Hydrograph, $V_{D R H}$. This volume must be equal to the volume of the Effective Rainfall Hyetograph (ERH).

$$
V_{D R H}=\int_{t} Q_{D R H}\left(t^{\prime}\right) d t^{\prime}
$$

where $t$ is the time. 
3. Express $V_{D R H}$ in equivalent units of depth, $V_{D R H D}$ :

$$
V_{D R H D}=V_{D R H} / A_{b a s i n}
$$

where Abasin is the basin area.

4. Obtain the UH by normalizing the $Q_{D R H}$. Normalizing implies dividing the ordinates of the $Q_{D R H}$ by the $V_{D R H}$ in equivalent units of depth in Equation (3).

$$
U H=Q_{D R H} / V_{D R H D}
$$

5. Determine the duration, $D$, of the ERH associated with the UH obtained in step 4 above.

Figure 2 shows the derivation of the UH for the Goose Creek watershed from the 10 December 2003 observed rainfall and discharge. In deriving the UH in Figure 2, Equations (1) through (4) were employed. Frequently, data are not available for isolated storms of sufficient runoff volume for the derivation of UHs. Because the requisite data are not available, the investigator must develop UHs from the records of complex storms with durations of rainfall excess that differ appreciably from the unit duration desired. In Figure 2, the 6-hour (hr) UH was derived from the $9 \mathrm{hr}$ UH from S-hydrographs (USACE NAB 1963). The guidelines for computation of Shydrographs and derivation of UHs from S-hydrographs is found in USACE NAB (1963).

Figure 2. Deriving a UH for the Goose Creek watershed.

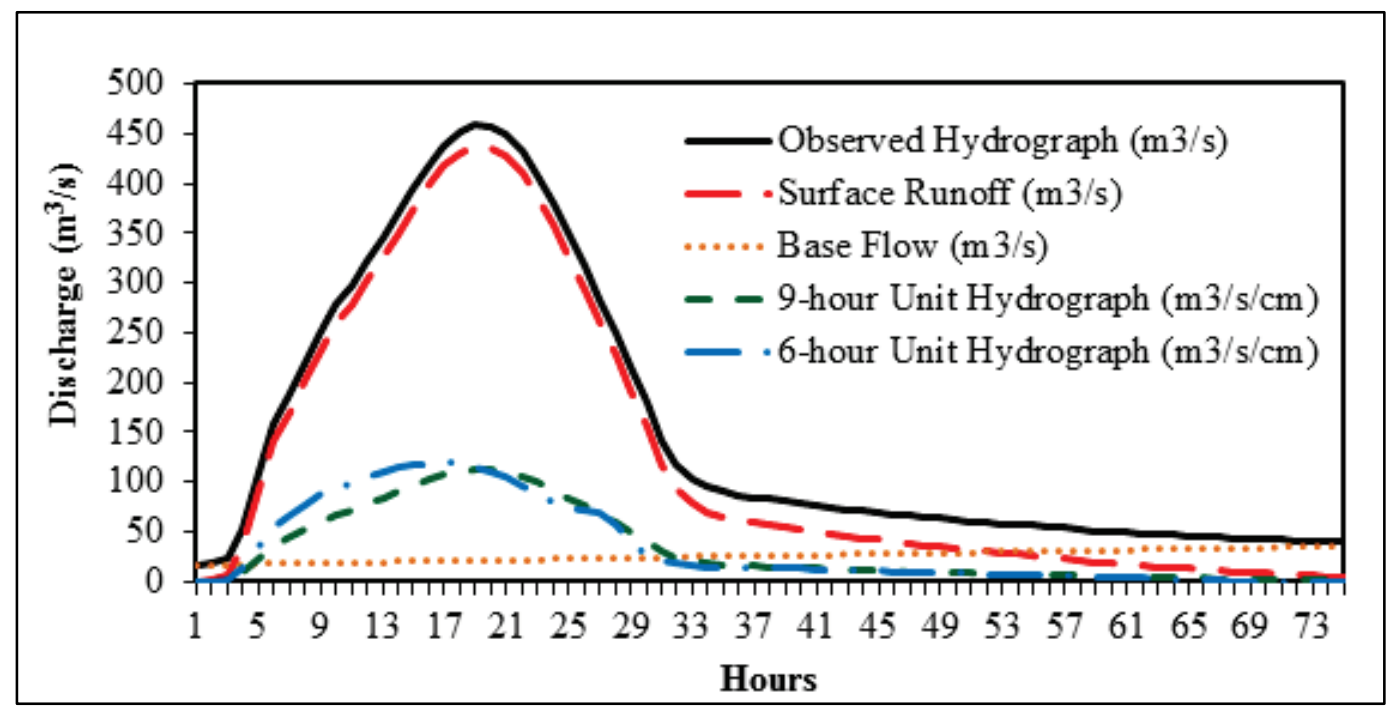




\subsection{Utilizing GSSHA to perform two-dimensional (2D) watershed modeling to derive a UH}

Hydrologic models play a significant role in transforming extreme return period rainfall events and probable maximum precipitation into corresponding design discharges. In this study, the physically based GSSHA model was deployed to obtain corresponding design discharge from probable rainfall events.

\subsubsection{GSSHA model simulation}

GSSHA computes one-dimensional (1D) infiltration, 2D overland flow, and $1 \mathrm{D}$ stream flow to simulate the overland runoff to streams and channel transport process to catchment outlet. The Green and Ampt infiltration scheme (Green and Ampt 1911) was employed to simulate the partitioning of input precipitation at the land surface. The runoff generated in each computational grid cell flows to adjacent cells through a 2D finite volume numerical scheme. Surface runoff is coupled to channel routing where lateral inflow from surface runoff grid cells is numerically routed through a 1D finite volume scheme.

\subsubsection{Infiltration model}

The infiltration model partitions the rainfall forcing into subsequent runoff. The rate of infiltration in the infiltration model is governed by the soil physical properties, which vary with the soil type. The soil map in Figure 3 was employed to define these properties. The following are the soil physical parameters specified in the infiltration model:

- effective porosity (cubic centimeter/cubic centimeter)

- field capacity (cubic centimeter/cubic centimeter)

- wilting point (cubic centimeter/cubic centimeter)

- residual saturation (cubic centimeter/cubic centimeter)

- pore size distribution (centimeter/centimeter)

- saturated hydraulic conductivity (centimeter/hour)

- wetting front suction head (centimeter). 
Figure 3. Goose Creek soil classification.

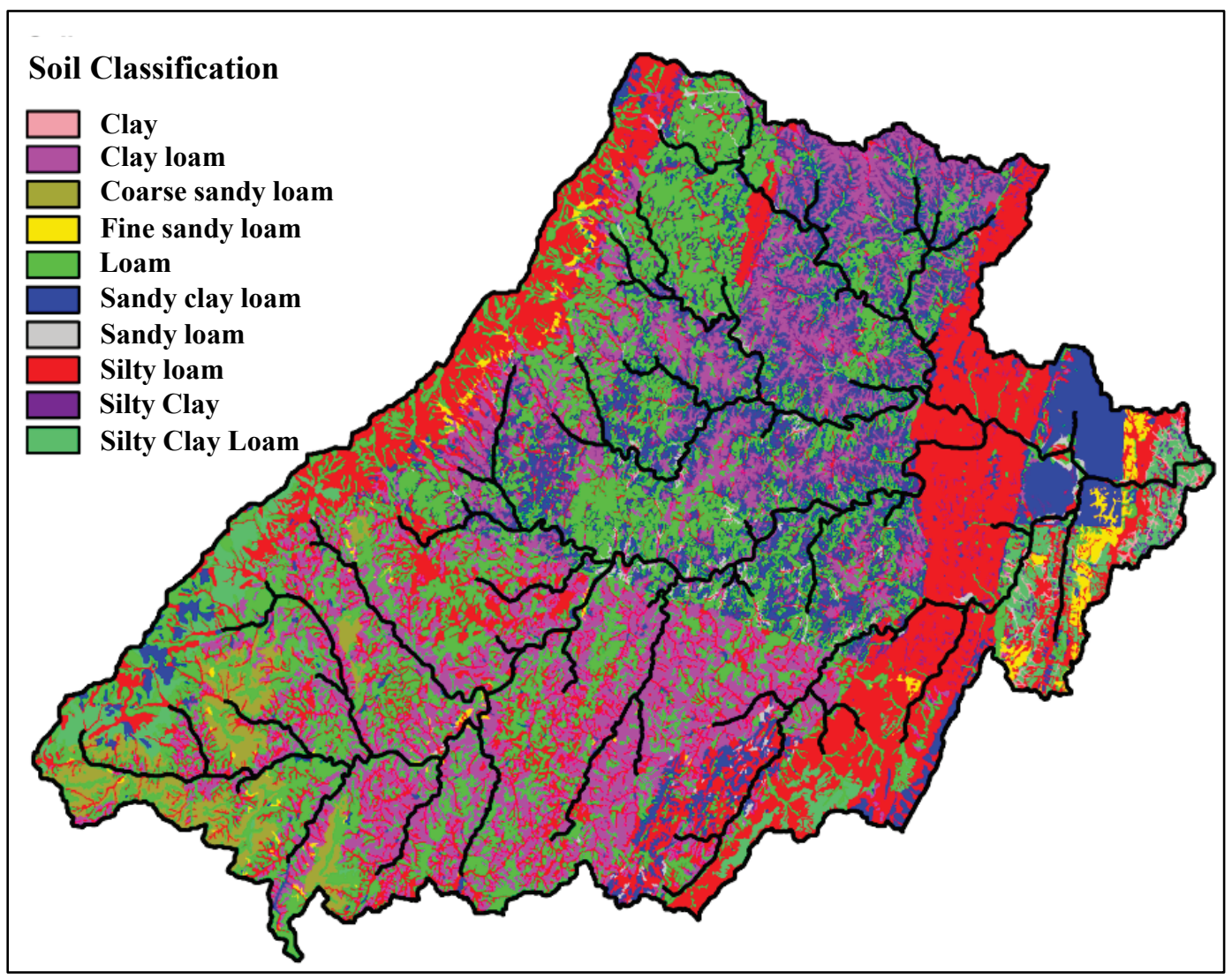

Apart from hydraulic conductivity, the parameters in Table 1 were obtained from Rawls et al. (1983) based on the soil classifications in Figure 3. Hydraulic conductivity in Table 1 was manually calibrated. To account for impervious land, developed areas in Figure 4 with more than 20\% impervious land cover were assigned a significantly lower value of hydraulic conductivity, 0.0005 centimeters/hour $(\mathrm{cm} / \mathrm{hr})$. This impervious developed area covers less than $3 \%$ of the watershed.

Table 1. Soil properties and infiltration parameters.

\begin{tabular}{|l|c|c|c|c|c|c|c|}
\hline Soil Type & $\begin{array}{l}\text { Hydraulic } \\
\text { Conductivit } \\
\mathbf{y} \\
(\mathrm{cm} / \text { hour })\end{array}$ & $\begin{array}{l}\text { Capillary Head } \\
(\mathbf{c m})\end{array}$ & $\begin{array}{l}\text { Porosity } \\
\left(\mathrm{cm}^{3} / \mathrm{cm}^{3}\right)\end{array}$ & $\begin{array}{l}\text { Pore Size } \\
\text { Distribution } \\
(\mathrm{cm} / \mathrm{cm})\end{array}$ & $\begin{array}{l}\text { Residual } \\
\text { Saturation } \\
\left(\mathrm{cm}^{3} / \mathrm{cm}^{3}\right)\end{array}$ & $\begin{array}{l}\text { Field } \\
\text { Capacity } \\
\left(\mathrm{cm}^{3} / \mathrm{cm}^{3}\right)\end{array}$ & $\begin{array}{l}\text { Wilting } \\
\text { Point } \\
\left(\mathrm{cm}^{3} / \mathrm{cm}^{3}\right)\end{array}$ \\
\hline Clay & 0.004 & 31.63 & 0.380 & 0.165 & 0.09 & 0.379 & 0.15 \\
\hline Clay loam & 0.004 & 20.88 & 0.385 & 0.242 & 0.075 & 0.375 & 0.15 \\
\hline $\begin{array}{l}\text { Coarse } \\
\text { sandy } \\
\text { loam }\end{array}$ & 0.012 & 11.01 & 0.390 & 0.378 & 0.041 & 0.375 & 0.095 \\
\hline
\end{tabular}




\begin{tabular}{|l|c|c|c|c|c|c|c|}
\hline Soil Type & $\begin{array}{l}\text { Hydraulic } \\
\text { Conductivit } \\
\mathbf{y} \\
(\mathbf{c m} / \text { hour })\end{array}$ & $\begin{array}{l}\text { Capillary Head } \\
(\mathbf{c m})\end{array}$ & $\begin{array}{l}\text { Porosity } \\
\left(\mathrm{cm}^{3} / \mathrm{cm}^{3}\right)\end{array}$ & $\begin{array}{l}\text { Pore Size } \\
\text { Distribution } \\
\left(\mathbf{c m} / \mathrm{cm}^{\prime}\right.\end{array}$ & $\begin{array}{l}\text { Residual } \\
\text { Saturation } \\
\left(\mathrm{cm}^{3} / \mathrm{cm}^{3}\right)\end{array}$ & $\begin{array}{l}\text { Field } \\
\text { Capacity } \\
\left(\mathrm{cm}^{3} / \mathrm{cm}^{3}\right)\end{array}$ & $\begin{array}{l}\text { Wilting } \\
\text { Point } \\
\left(\mathrm{cm}^{3} / \mathrm{cm}^{3}\right)\end{array}$ \\
\hline $\begin{array}{l}\text { Fine sandy } \\
\text { loam }\end{array}$ & 0.012 & 11.01 & 0.390 & 0.378 & 0.041 & 0.370 & 0.095 \\
\hline Loam & 0.005 & 8.89 & 0.400 & 0.252 & 0.027 & 0.375 & 0.117 \\
\hline $\begin{array}{l}\text { Sandy clay } \\
\text { loam }\end{array}$ & 0.001 & 21.85 & 0.380 & 0.319 & 0.068 & 0.375 & 0.148 \\
\hline $\begin{array}{l}\text { Sandy } \\
\text { loam }\end{array}$ & 0.012 & 11.01 & 0.395 & 0.378 & 0.041 & 0.375 & 0.095 \\
\hline Silt loam & 0.004 & 16.68 & 0.410 & 0.234 & 0.015 & 0.375 & 0.15 \\
\hline Silty clay & 0.008 & 29.22 & 0.395 & 0.15 & 0.056 & 0.378 & 0.15 \\
\hline $\begin{array}{l}\text { Silty clay } \\
\text { loam }\end{array}$ & 0.008 & 27.3 & 0.410 & 0.177 & 0.04 & 0.376 & 0.15 \\
\hline
\end{tabular}

Figure 4. Goose Creek land use.

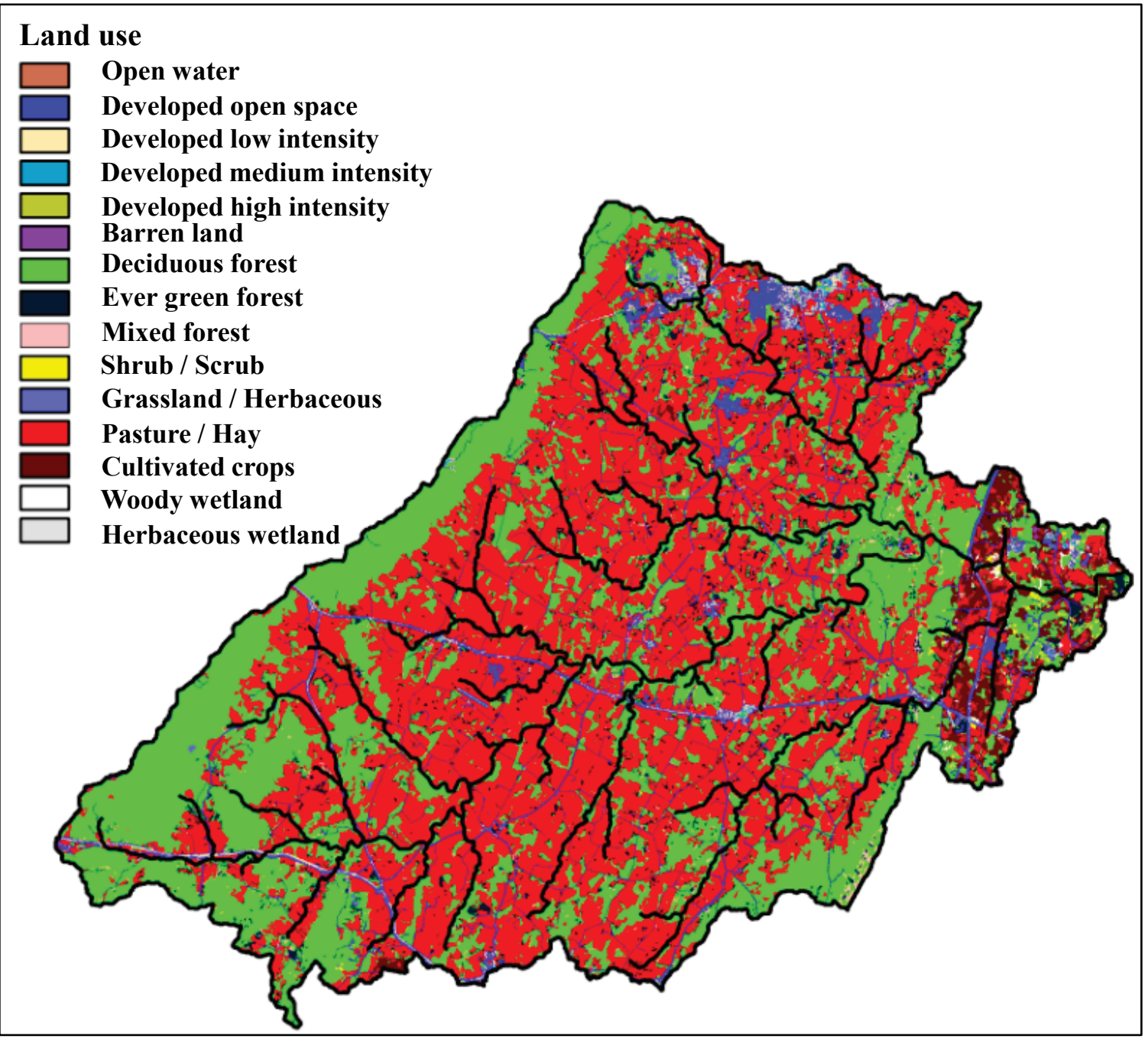




\subsubsection{Routing model}

GSSHA employs an explicit finite volume scheme to route water for both 1D channel flow and 2D overland flow, where flow rates are computed based on heads, and volumes are updated based on the computed flow rates. The friction slope between one grid cell and its neighbors is calculated as the difference in water surface elevations divided by the grid cell size. Compared with the kinematic wave approach, this diffusive wave approach allows GSSHA to route water through pits or depressions and regions of adverse slope. Manning's equation (Manning 1891) relates normal flow depth to discharge. Hydrological models implement Manning's equation to relate surface roughness to flow rate, in which case the hydraulic roughness is represented by the Manning's roughness coefficient, $n$. For each land use type shown in Figure 4, a Manning's roughness coefficient, $n$, was calibrated within the ranges listed on the GSSHA wiki (http://www.gsshawiki.com/Surface_Water_Routing:OVerland_Flow_Routing). Table 2 lists the calibrated Manning's roughness coefficients in the study area.

Table 2. Land use type and overland flow hydraulic roughness.

\begin{tabular}{|l|l|}
\hline Land use type & Roughness \\
\hline Water & 0.045 \\
\hline Developed (impervious 20\%) & 0.3 \\
\hline Developed (impervious 20-49\%) & 0.07 \\
\hline Developed (impervious 50-79\%) & 0.013 \\
\hline Developed (impervious 80-100\%) & 0.011 \\
\hline Barren land (vegetation <15\%) & 0.4 \\
\hline Deciduous forest & 0.492 \\
\hline evergreen forest & 0.492 \\
\hline mixed forest & 0.492 \\
\hline Shrub & 0.48 \\
\hline Grassland & 0.45 \\
\hline Pasture & 0.45 \\
\hline Cultivated & 0.45 \\
\hline Woody wetlands & 0.45 \\
\hline Herbaceous wetlands & 0.45 \\
\hline
\end{tabular}




\subsubsection{Calibration}

The model was calibrated to the 9 December 2003 event as shown in Figure 5.

Figure 5. Goose Creek catchment GSSHA calibration (Nash-Sutcliffe Efficiency was $90 \%$ ).

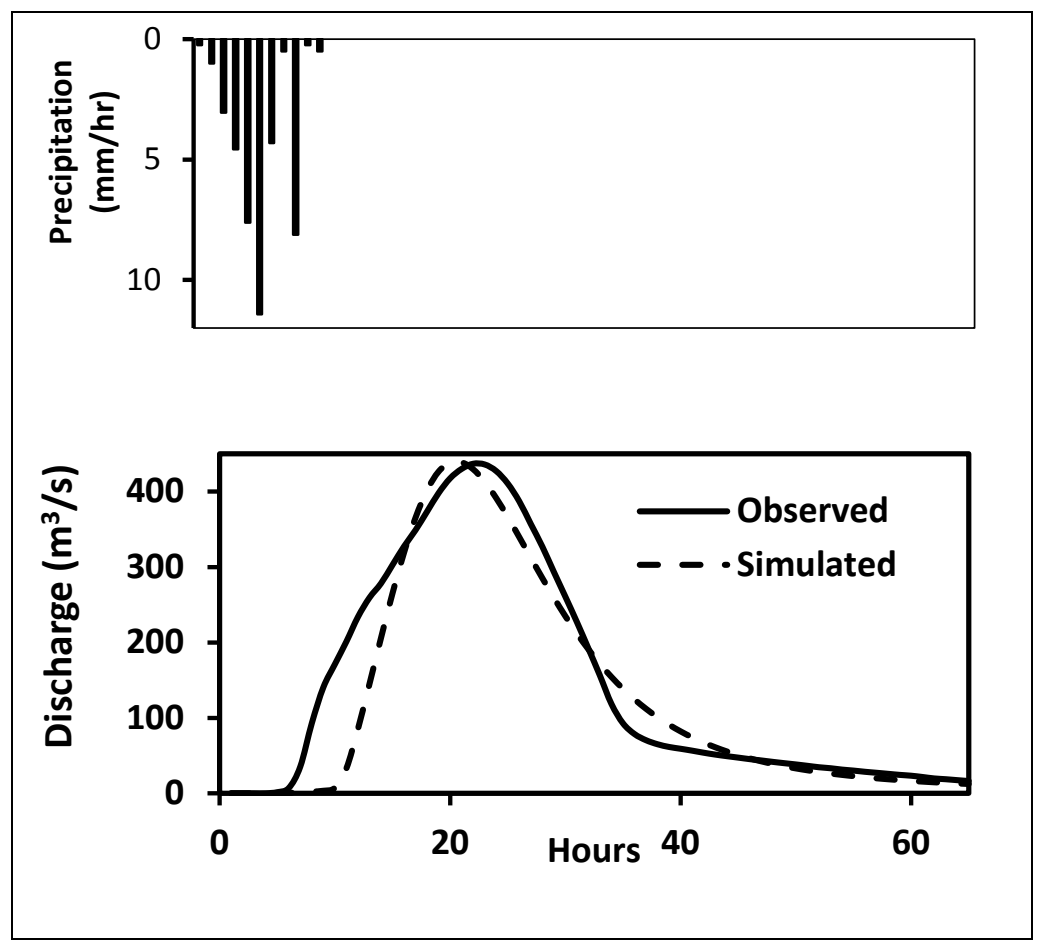

The calibrated model was then deployed to simulate the various return period events. 


\section{Results and Discussion}

The $6 \mathrm{hr}$ historic cumulative event precipitation was obtained from the NOAA ATLAS 14 Precipitation Frequency Data Server (PFDS), http://hdsc.nws. noaa.gov/hdsc/pfds/. The PFDS gives the 1-year, 5-year, 10-year, 25-year, 50-year, and 100-year return period events in the Goose Creek watershed as shown in Figure 6. To derive these series, NOAA collects precipitation measurements from all available sources, performs data correction and outlier removal, and computes extreme event magnitudes with confidence intervals for various durations and return periods. Following an initial data correction process, the annual maximum series is extracted at each measurement site for common durations of interest. A generalized extreme value distribution (GEV) is then fitted to the annual maximum series using L-moments with final distribution parameters obtained by a regional average. The GEV distribution provides the likelihood of a particular magnitude occurring for the extracted duration, which permits the annual exceedance probability to be determined. The return period of an event magnitude can be directly obtained from the inverse of the annual exceedance probability. Common event durations and return periods are summarized in the PFDS, which also provides gridded interpolation between gages.

Additionally, NOAA determines data processing confidence intervals by applying a Monte Carlo procedure to the GEV distribution to obtain the 90\% confidence limit (the $5 \%$ lower bound and 95\% upper bound). NOAA confidence limits only characterize the certainty of the data processing technique used to obtain the return period estimates. Additional sources of uncertainty, such as gage clustering and imperfect historical knowledge, are not represented and would only increase the NOAA-calculated uncertainty limit. However, the user of GEV data must account for the statistical confidence during hydrologic analysis. The NOAA confidence intervals at each return period were applied to the watershed and are given in Figure 6.

NOAA Precipitation Frequency Atlas also provides the temporal event profiles. Event accumulation rates were determined by applying a fixed window at the selected duration to the precipitation series. The deciles of the accumulation rate for each duration are provided graphically from 
these events. In addition, the event temporal distributions are further divided into quartiles by magnitude and the accumulation deciles calculated for each magnitude quartile. In Figure 6, design return period events were created by choosing $6 \mathrm{hr}$ accumulation return period precipitation magnitudes in combination with an appropriate temporal distribution provided by the NOAA PFDS, http://hdsc.nws.noaa.gov/hdsc/pfds/pfds_temporal.html.

Figure 6. NOAA Atlas $14 ; 6 \mathrm{hr}$ return period precipitation event temporal distribution estimation in the study area.

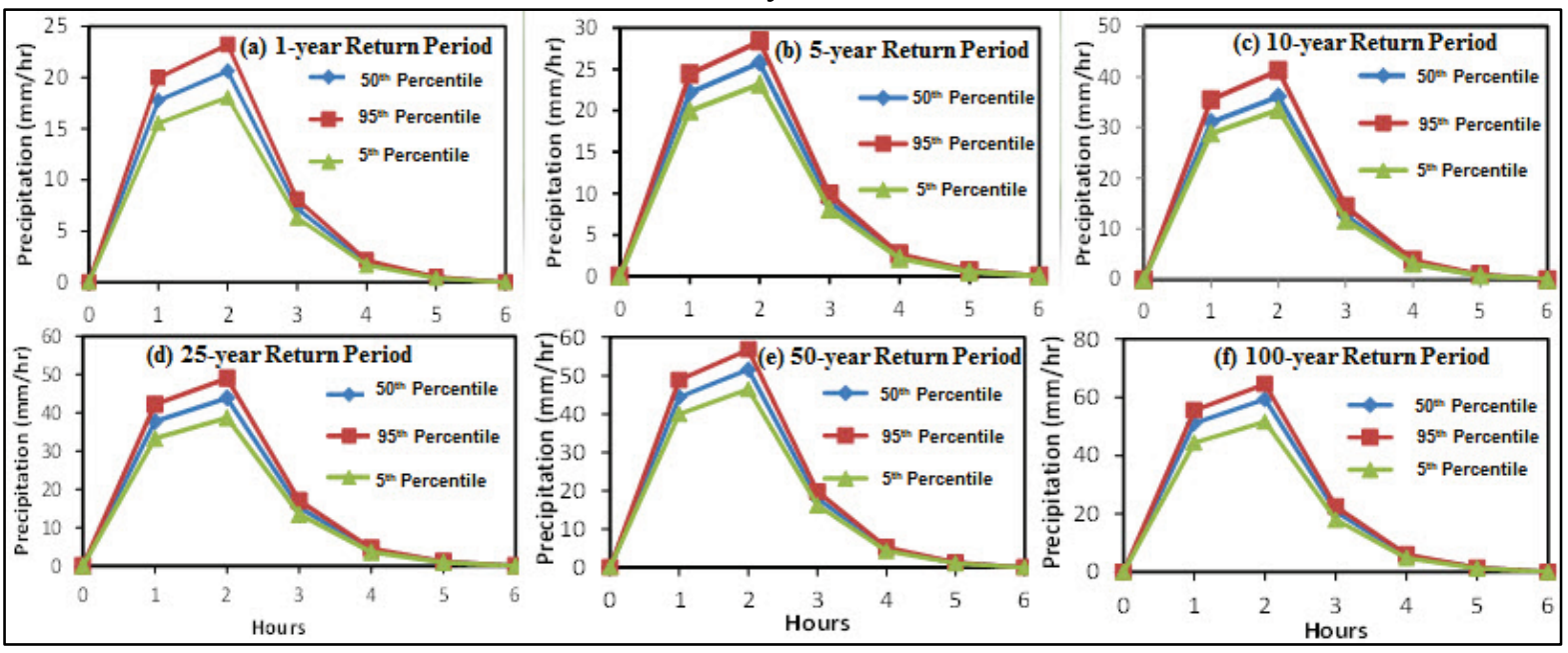

The return period events shown in Figure 6 along with the PMP event are deployed in the calibrated GSSHA model. Figure 7 shows the GSSHA model runoff simulation of the return period events.

Figure 7. NOAA 50th percentile return period discharge from GSSHA simulations.

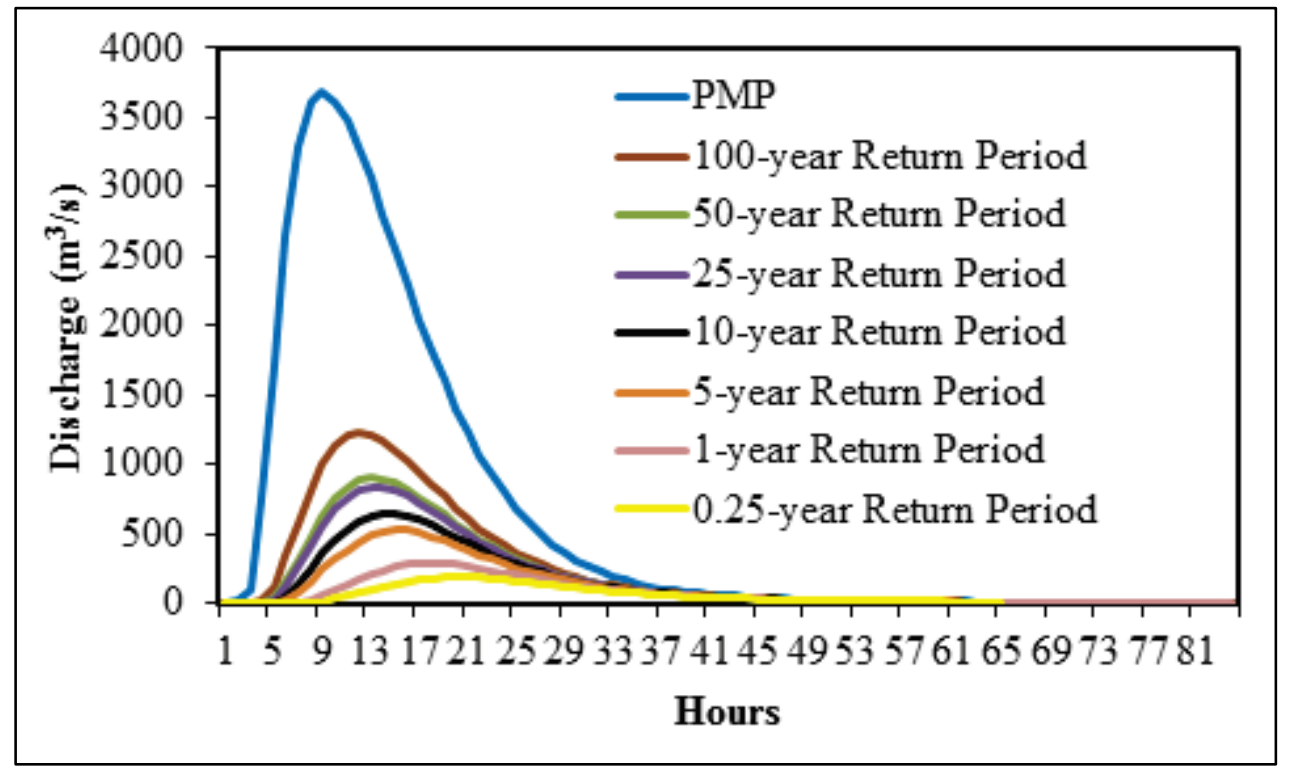


Figure 8 shows the UH obtained from the GSSHA model runoff simulations in Figure 7. The procedure followed in deriving the UH in Figure 8 is described in section 4.3.1 where the GSSHA-simulated runoff was employed instead of observed runoff.

Figure 8. NOAA 50th percentile return period UH from GSSHA simulations.

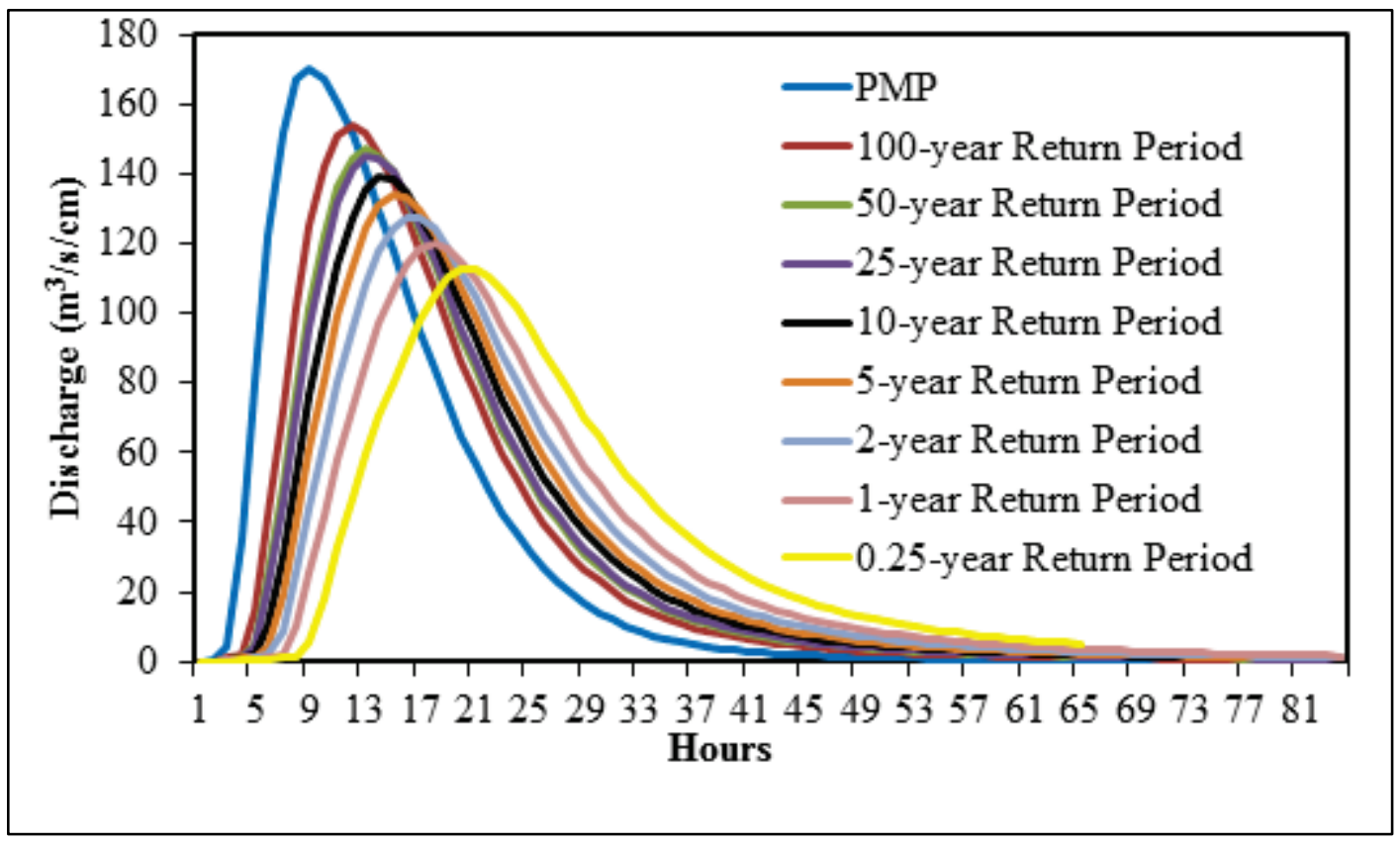

Table 3 shows the derivation of the peaking factor in terms of 0.25 -year return period to 100-year return period. In Table 3, the values under the headings "Peaking Factor in terms of," "X-year Return Period," are the peaking factors representing the $\mathrm{X}$-year return period, where $\mathrm{X}$ ranges from 0.25 to 100 . The $\mathrm{X}$-year return period peaking factors in the rows are the UH peak values of the corresponding event types under heading "Event type" normalized by UH peak value for that X-year return period. UH peak values are defined under heading "Unit hydrograph peak." For example, if the $\mathrm{X}$ is 0.25 , all the $\mathrm{UH}$ peak values, from 0.25 -year return period to PMP, are divided by the UH peak value of 0.25 -year return period that is 112.6 centimeters/second/centimeter $(\mathrm{cm} / \mathrm{s} / \mathrm{cm})$ in Table 3 . Therefore, Table 3 represents a sensitivity analysis of the peaking factor to the return period used to normalize the peak of the UHs. Figure 9 was developed to illustrate Table 3, where four bands are defined based on the peaking factor value: "Safe" if the peaking factor is less than 1.0; "Moderately Safe" if between 1 and 1.3; "Critical" if between 1.3 and 1.5; and "Risky" if exceeding 1.5. Figure 9 shows that the UHs developed from events at or above the 5-year return period are well within the 1.25 to 1.5 
peaking factor range. The UHs developed from 5 -year return period and above fall into either the Safe or Moderately Safe band in Figure 9. Table 3 and Figure 9 also show that the peaking factor from the 1-year return period rainfall UH is close to 1.5 at the PMP. In other words, the 1-year return period UH may fall into the Critical band, as shown in Figure 9. Table 3 and Figure 9 show that peaking factor from UH of the 0.25-year event is greater than 1.5 at PMP. That is, a 0.25 -year return period UH may fall into the "Unsafe" band, as shown in Figure 9.

Table 3. Derivation of the peaking factor in terms of GSSHA-simulated NOAA 50th percentile 0.25-year return period to 100 -year return period in the Goose Creek Catchment.

\begin{tabular}{|c|c|c|c|c|c|c|c|c|}
\hline \multirow[b]{2}{*}{ Event Type } & \multirow[b]{2}{*}{$\begin{array}{l}\text { UH Peak } \\
\left(\mathrm{m}^{3} / \mathrm{s} / \mathrm{cm}\right)\end{array}$} & \multicolumn{7}{|c|}{ Peaking Factor in Terms of } \\
\hline & & $\begin{array}{l}\text { 0.25-year } \\
\text { Return } \\
\text { Period }\end{array}$ & $\begin{array}{l}\text { 1-year } \\
\text { Return } \\
\text { Period }\end{array}$ & $\begin{array}{l}\text { 5-year } \\
\text { Return } \\
\text { Period }\end{array}$ & \begin{tabular}{|l} 
10-year \\
Return \\
Period
\end{tabular} & \begin{tabular}{|l} 
25-year \\
Return \\
Period
\end{tabular} & $\begin{array}{l}\text { 50-year } \\
\text { Return } \\
\text { Period }\end{array}$ & \begin{tabular}{|l} 
100-year \\
Return \\
Period
\end{tabular} \\
\hline $\begin{array}{l}\text { 0.25-year } \\
\text { Return Period }\end{array}$ & 112.600 & 1.000 & 0.939 & 0.840 & 0.811 & 0.777 & 0.767 & 0.732 \\
\hline $\begin{array}{l}\text { 1-year Return } \\
\text { Period }\end{array}$ & 119.900 & 1.065 & 1.000 & 0.895 & 0.863 & 0.827 & 0.816 & 0.780 \\
\hline $\begin{array}{l}\text { 5-year Return } \\
\text { Period }\end{array}$ & 134.000 & 1.190 & 1.118 & 1.000 & 0.965 & 0.924 & 0.912 & 0.871 \\
\hline $\begin{array}{l}\text { 10-year Return } \\
\text { Period }\end{array}$ & 138.900 & 1.234 & 1.158 & 1.037 & 1.000 & 0.958 & 0.946 & 0.903 \\
\hline $\begin{array}{l}\text { 25-year } \\
\text { Return Period }\end{array}$ & 145.000 & 1.288 & 1.209 & 1.082 & 1.044 & 1.000 & 0.987 & 0.943 \\
\hline $\begin{array}{l}\text { 50-year } \\
\text { Return Period }\end{array}$ & 146.900 & 1.305 & 1.225 & 1.096 & 1.058 & 1.013 & 1.000 & 0.955 \\
\hline $\begin{array}{l}\text { 100-year } \\
\text { Return Period }\end{array}$ & 153.800 & 1.366 & 1.283 & 1.148 & 1.107 & 1.061 & 1.047 & 1.000 \\
\hline PMP & 170.400 & 1.513 & 1.421 & 1.272 & 1.227 & 1.175 & 1.160 & 1.108 \\
\hline
\end{tabular}


Figure 9. Peaking factor sensitivity analysis chart.

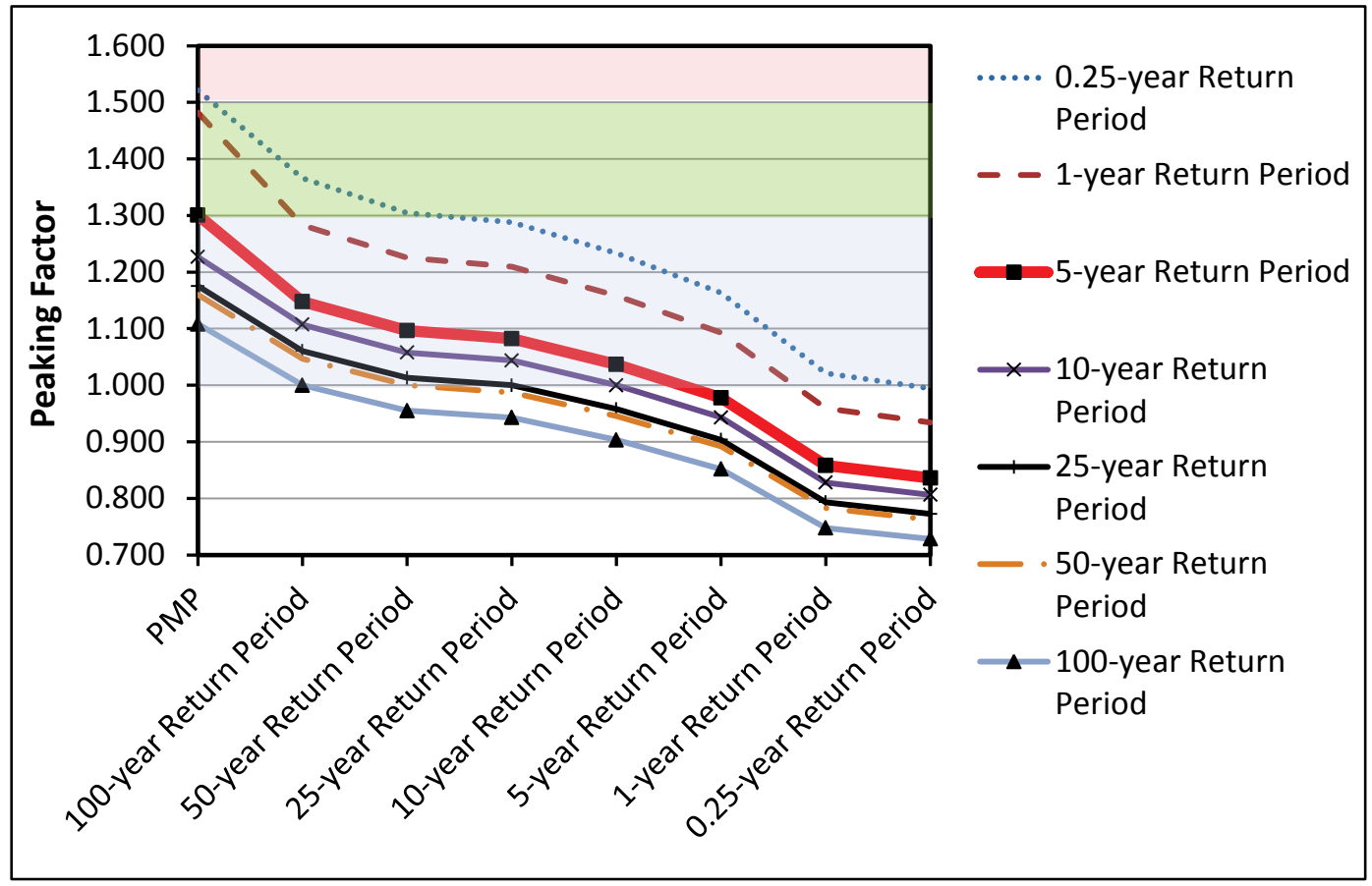

This case study in the Goose Creek watershed found that the upper limit of the UHPF for the UH peak published in the USACE NAB (1963) report was 0.9 and that for the UH in Figure 2 was 1.4. The average rainfall published in the USACE NAB (1963) report was 135 millimeters (mm) in $36 \mathrm{hr}$. This rainfall is equivalent to 25-year return period rainfall as per the PFDS report. The peak of the derived 6-hour UH for the USACE NAB (1963) published report was 189 cubic meters/second/centimeter $(\mathrm{m} 3 / \mathrm{s} / \mathrm{cm})$. The rainfall for Figure 2 was $42 \mathrm{~mm}$ in $12 \mathrm{hr}$, which is equivalent to 1-year return period rainfall as per the PFDS report.

Figure 10 shows the peaking factor and effective rainfall relationship as defined by Equation (5).

$$
y=2.486 x^{-0.179}
$$

The relationship defined with Equation (5) had the coefficient of determination of 0.9406 . 
Figure 10. Peaking factor and effective rainfall relationship.

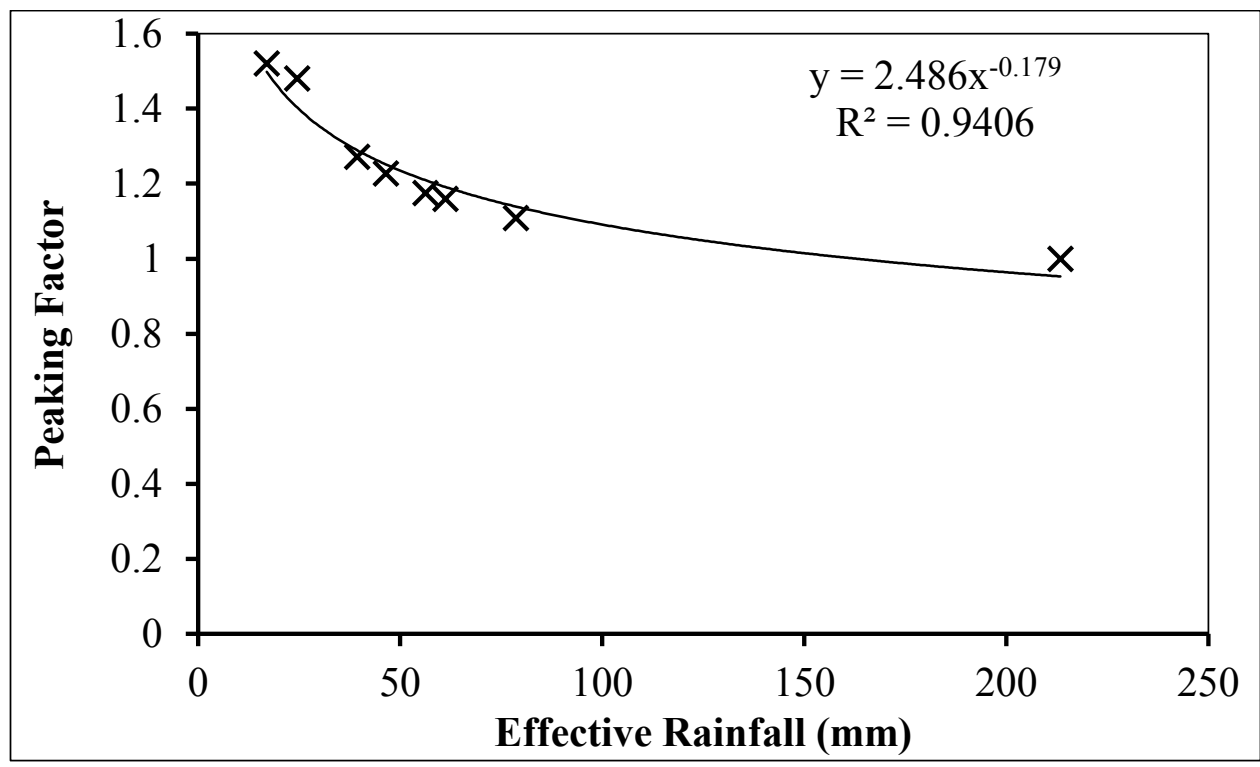

The use of a single, deterministic reference hydrograph to establish an acceptable peaking factor implies that the full flood and precipitation frequency curves are known with certainty. As complete knowledge is rarely available; the use of probabilistic techniques can be used to capture the various sources of uncertainty to establish a peaking factor confidence interval. The range and maximum value of the interval can then be incorporated as part of a dam safety assessment as a measure of risk.

Uncertainty can be introduced from both the input data as well as the data analysis procedure. The present analysis is confined to the latter introduced by the NOAA precipitation analysis procedure; the uncertainty associated with input data and other processes can be readily incorporated through a joint probability analysis.

NOAA Atlas 14 provides three precipitation depths occurring at the $5^{\text {th, }}$ 50th, and 95th confidence intervals that equally satisfy the return period as a result of its Monte Carlo data analysis procedure. Selection of any depth that satisfies the confidence intervals would be an acceptable event to represent the return period of interest. The confidence interval range that is produced may be quite large in many cases. The range in the calculated precipitation depth data analysis confidence intervals is a proxy for the amount of risk accepted by an installation if data processing uncertainty is not considered when calculating the peaking factor. If a precipitation depth and resulting flood at a low confidence interval is utilized as the design event, the peaking factor may be underestimated, resulting in an unsafe design. Similarly, if a precipitation depth and flood 
at a high confidence interval is utilized as the norming event, a design may be overly conservative leading to increased construction/maintenance costs.

The effect of data processing uncertainty on peaking factors at Goose Creek was determined by applying the $5 \%$ and $95 \%$ confidence interval precipitation depths to the watershed in addition to the $50 \%$ value.

Figure 11 shows the variation in the peaking factor at each return period, normalized to the 5 -year, 5 oth percentile value. The 5oth percentile is given by the black line; the 95th percentile is given by the upper error bar and the $5^{\text {th }}$ by the lower error bar. The difference between the $5^{\text {th }}$ and 95th percentile is as large as 0.052 for the 50-year return period, $4.7 \%$ of the 5oth percentile value. While not evident directly at the Goose Creek watershed, this difference in the selected precipitation depth due to data processing uncertainty alone is sufficiently large that it could cause some reference events to become inadequate at maintaining a peaking factor below 1.5 at other watersheds. The large difference between the percentiles supports greater conservativeness in choosing the precipitation depth confidence level used to establish peaking factors.

Figure 11. Peaking factor as a function of return period and data processing uncertainty interval for the precipitation depths specified by NOAA Atlas 14 that were applied to the hydrologic model. The black line gives the 50th percentile peaking factor with lower and upper bars giving the 5th and 95th percentiles, respectively.

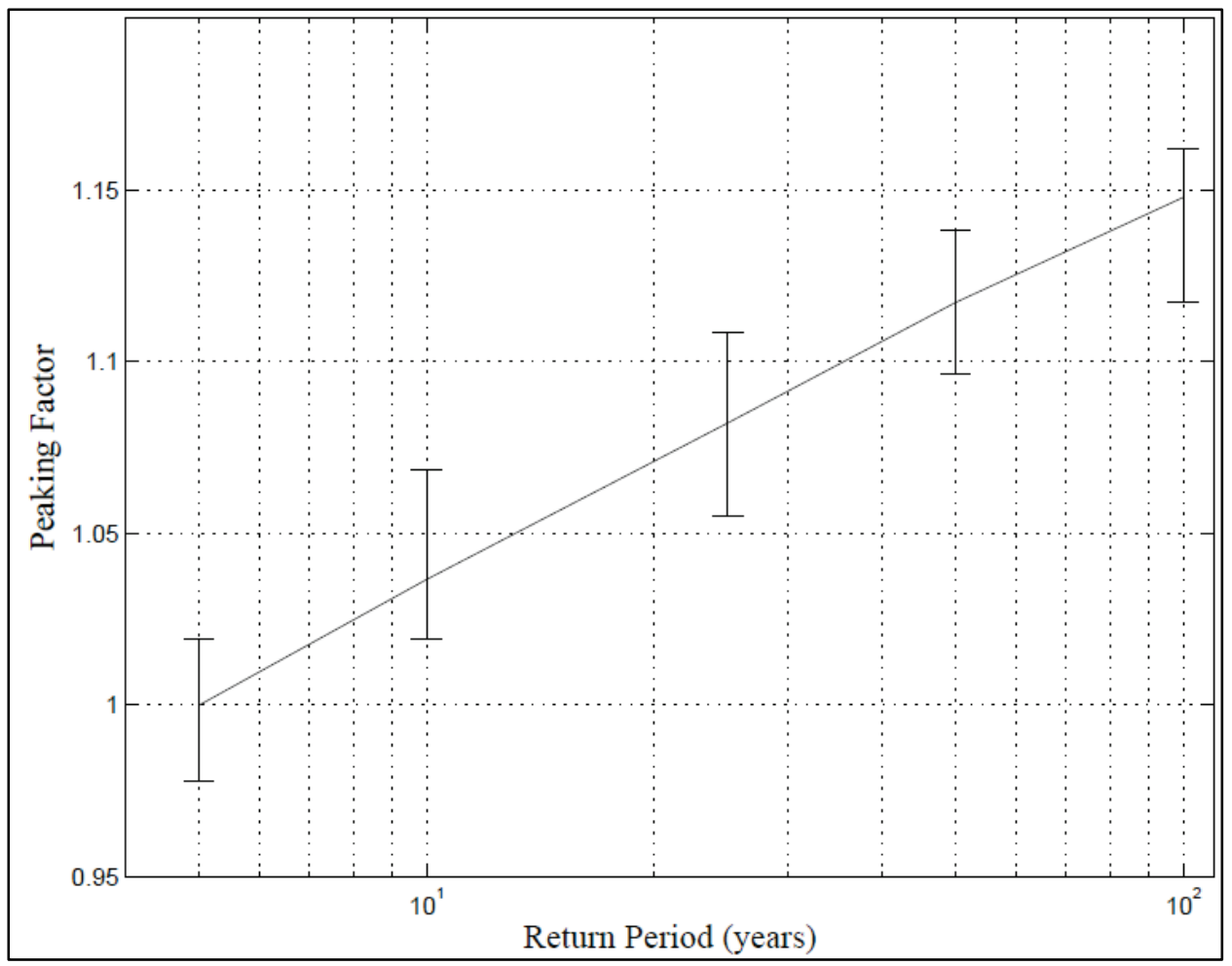


Knowledge of the peaking factor as a function of return period permits inverse calculation for the return period associated with a desired peaking factor magnitude. This knowledge is again useful as a proxy for the amount of risk accepted during a peaking factor analysis. As excess precipitation is linear with increasing precipitation depth, a simple logarithmic transform is typically sufficient to extrapolate the peaking factor beyond modeled return periods. By taking the normalization events at increasing confidence intervals to obtain the peaking factor trend and extrapolating the return period at the desired peaking factor, a range of return periods can be established from lowest (safest) to highest (least safe). The span of the size of the return period range informs one as to how sensitive the analysis is to the normalization value. Equally the lowest range value can determine if a design is sufficiently conservative to meet the return period requirements at the maximum accepted peaking factor.

The procedure above can be applied to determine a return period associated with the PMP as well as the commonly utilized maximum peaking factor value of 1.5. Although by definition the PMP does not have a return period, it is nonetheless a useful exercise. The intersection of the peaking factor trend line with the peaking factor evaluated at the PMP represents the location where the curve in Figure 10 becomes asymptotic. The magnitude of the return period at the intersection characterizes the maximum protection of the system under the assumptions used to formulate the peaking factor analysis. Table 4 gives the expression for the trend line at each confidence percentile in Figure 11 as well as the coefficient of determination. The fit to each trend line, and in particular the 5oth percentile, correlates highly to the calculated peaking factors.

Table 4. Equations of fit for the peaking factor analysis in Figure 11 for the considered data analysis confidence intervals.

\begin{tabular}{|l|c|l|}
\hline Percentile & Function & $\mathrm{R}^{2}$ \\
\hline 5th & $P F(y)=0.0468 \ln (y)+0.9066$ & 0.9909 \\
\hline 50th & $P F(y)=0.0495 \ln (y)+0.9993$ & 0.9993 \\
\hline 95th & $P F(y)=0.0467 \ln (y)+0.9532$ & 0.9837 \\
\hline
\end{tabular}

The return period for the PMP peaking factor and peaking factor of 1.5 are approximated by inverting each function in Table 4 to solve for the return period as a function of peaking factor. The results for each percentile are given in Table 5. A lower uncertainty percentile results in a larger return period for the PMP and peaking factor of 1.5. This follows intuition as a 
longer return period is required for smaller magnitude events to reach the same peaking factor. The 50th and 95th percentiles show reversed behavior for the maximum peaking factor. This inversion is a result of the variability in the Monte Carlo procedure used by NOAA to establish the confidence intervals. Their difference, however, is not as great as the difference between either and the $5^{\text {th }}$ percentile. The $5^{\text {th }}$ percentile predicts almost a three times greater return period at the maximum accepted peaking factor than the 50th and 95th percentiles. A similar magnitude difference is also present between the $5^{\text {th }}$ and 95th percentiles of the PMP return period. The range in return period at the PMP peaking factor is approximately 1500 years while that of the 1.5 peaking factor is nearly 200,000 years. The extent of both ranges demonstrates the importance of accounting for uncertainty when conducting a peaking factor analysis to ensure a conservative design.

Table 5. Return period for the PMP and maximum accepted peaking factor as calculated by inverting the functions fit the peaking factor/return period relationship. The form of each function is given in Table 4.

\begin{tabular}{|l|l|l|}
\hline Percentile & PMP Return Period (years) & $\begin{array}{l}\text { Maximum Peaking Factor (1.5) } \\
\text { Return Period (years) }\end{array}$ \\
\hline 5 th & 2441 & 321093 \\
\hline 50 th & 1173 & 118280 \\
\hline 95th & 915 & 121635 \\
\hline
\end{tabular}




\section{Conclusions}

This research utilized the GSSHA model in the Goose Creek watershed to calculate the discharge from design events with various magnitudes of excess rainfall while including the non-linear component of the watershed response. The discharges were then used to develop the UHPF relationship with rainfall excess. The UH results obtained at various return periods demonstrate that the peaking factor from a 5 -year return period was well within 1.25 to 1.5 limits. In contrast, the UH derived from events less than 5 -year return period exceeded the 1.25 to 1.5 peaking factor limits. Goose Creek unit hydrograph was designed from rainfall event equivalent to 25-year return period rainfall and therefore ensures dam safety given the current UHPF guidance. This study also developed peaking factors' relationship with excess rainfall in the Goose Creek watershed. This peaking factors' relationship with excess rainfall was found to be non-linear.

In the present case study, the land use change effects are not taken into consideration as the urbanization and development within the study watershed is not significant as the impervious area is less than $3 \%$ of the catchment area. Yet, there are other watersheds where the land use change is significant (e.g., Ogden et al. 2011), which requires an analysis of the land use change effect in the hydrologic numerical simulations for peaking factor analysis. A further study would be to develop a regionalized peaking factor relationship with excess rainfall based on the climatic regions of continental United States. That way, the transposition of UHPF and peaking factors' relationship with excess rainfall between watersheds with similar climates can be readily investigated. A regionalized watershed characteristics relationship also provides guidance and quick information for prediction, flood hazard assessment, or design purposes on ungauged basins (Ding 2011; Pradhan et al. 2016). In this study, the assumption has been made that the data processing confidence interval can be taken as an initial proxy of the total precipitation depth uncertainty. Imperfect knowledge of the true precipitation depth at each return period must also be accounted for to ensure the reference event has a sufficiently large magnitude to maintain dam safety. Ideally, such an analysis would consider all sources of uncertainty from the watershed such as antecedent conditions, storm spatial/temporal properties, and data processing decisions, which is left as a topic for further research. 


\section{References}

Childs, E. F. 1958. Northeastern floods of 1955: flood control hydrology. J. Hydraul. Div. 84(HY3):1663.1-1963.24.

Ding, J. Y. 1974. Variable unit hydrograph. J. Hydrol. 22(1-2):53-69. doi:10.1016/00221694(74)90095-x.

Ding, J. Y. 2011. A measure of watershed nonlinearity: interpreting a variable instantaneous unit hydrograph model on two vastly different sized watersheds. Hydrol. Earth Syst. Sci. 15(1):405-423. doi:10.5194/hess-15-405-2011.

Downer C. W., and F. L. Ogden. 2004. GSSHA: model to simulate diverse streamflow producing processes. J. Hydrol. Eng. 9(3):161-74. doi:10.1061/(asce)1084-0699(2004)9:3(161).

Downer C. W, N. R. Pradhan, F. L. Ogden, and A. Byrd. 2015. Testing the effects of detachment limits and transport capacity formulation on sediment runoff predictions using the US Army Corps of Engineers GSSHA model. ASCE, Journal of Hydrologic Engineering. doi: 10.1061/(ASCE)HE.1943-5584.0001104.

Downer C., J. A. Graulau-Santiago, B. E. Skahill, D. M. Weston, N. Pradhan, and A. R. Byrd. 2016. Gridded surface subsurface hydrologic analysis modeling for analysis of flood design features at the Picayune Strand restoration project. ERDC/CHL TR-16-14. Vicksburg, MS: U.S. Army Engineer Research and Development Center. http://hdl.handle.net/11681/20298.

Green, W. H., and G. A. Ampt. 1911. Studies of soil physics: 1. Flow of air and water through soils J. Agric. Sci. 4:1-24.

Hendrickx J. M. H., R. G. Allen, A. Brower, A. R. Byrd, S-ho Hong, F. L. Ogden, N. R. Pradhan, C. W. Robison, D. Toll, R. Trezza, T. G. Umstot, J. L Wilson. 2016. Benchmarking optical/thermal satellite imagery for estimating evapotranspiration and soil moisture in decision support tools. JAWRA Journal of the American Water Resources Association 52(1):89-119. doi:10.1111/1752-1688.12371.

Hershfield D. M. 1961. Rainfall frequency atlas of the United States: for durations from 30 minutes to 24 hours and return periods from 1 to 100 years. Technical Paper No. 40. Washington, DC: Department of Commerce, Weather Bureau.

Kokkonen, T., H. Koivusalo, T. Karvonen, B. Croke, and A. Jakeman. 2004. Exploring streamflow response to effective rainfall across event magnitude scale. Hydrol. Process. 18(8):1467-1486. doi:10.1002/hyp.1423.

Manning, R. 1981. On the flow of water in open channels and pipes. Transactions of the Institution of Civil Engineers of Ireland 20:161-207.

Massey, T. C., N. R. Pradhan, A. R. Byrd, D. E. Cresitello. 2013. USACE-ERDC coastal storm modelling systems in support of Hurricane Sandy operations. Flood Risk Manage. Newslett. 6(4):2-3. 
Linsley, R. K., M. A. Kohler, and J. L. H. Paulhus. 1975. Hydrology for engineers. New York: McGraw-Hill.

Minshall, N. E. 1960. Predicting storm runoff on small experimental watersheds. $J$. Hydraul. Div., Am. Soc. Civ. Eng. 86(HY8):17-38.

Ogden, F. L., N. R. Pradhan, C. W. Downer, and J. A. Zahner. 2011. Relative importance of impervious area, drainage density, width function and subsurface storm drainage on flood runoff from an urbanized catchment. Water Resources Research 47 (12):W12503-1-W12503-12. doi:10.1029/2011wro10550.

Pradhan N. R., and F. L. Ogden. 2010. Development of a one-parameter variable source area runoff model for ungauged basins. Advances in Water Resources 33(5):572-584. doi: 10.1016/j.advwatres.2010.03.002.

Pradhan, N. R, A. R. Byrd, F. L. Ogden, J. M. H. Hendrickx. 2012. SEBAL evapotranspiration estimates for the improvement of distributed hydrological model runoff and soil moisture predictions. In Remote Sensing and Hydrology, Proceedings of a Symposium, Jackson Hole, Wyoming, September 2010, IAHS Publication 352, 435-439.

Pradhan, N. R, C. W. Downer, and B. E. Johnson. 2014. A physics based hydrologic modeling approach to simulate non-point source pollution for the purposes of calculating TMDLs and designing abatement measures. In Practical Aspects of Computational Chemistry III, edited by J. Leszczynski and M. K. Shukla, 249282. Boston, MA: Springer. doi:10.1007/978-1-4899-7445-7_9.

Pradhan, N. R., A. R. Byrd, M. Jourdan, and J. Ellis. 2016. Development of predictive relationships for the estimates of a return period flood effects in ungaged basins. ERDC/CHL CHETN-VIII-8. Vicksburg, MS: U.S. Army Engineer Research and Development Center.

Rawls, W. J., D. L. Brakensiek, and N. Miller. 1983. Green-Ampt infiltration parameters from soils data. J. Hydraul. Eng. 109:62-70.

Sanford, W. E., D. L. Nelms, J. P. Pope, and D. L. Selnick. 2012. Quantifying components of the hydrologic cycle in Virginia using chemical hydrograph separation and multiple regression analysis. Scientific Investigations Report 2011-5198. Reston, VA: U.S. Department of the Interior, U.S. Geological Survey. https://pubs.usgs.gov/sir/2011/5198/pdf/2011-5198.pdf.

Sherman, L. K. 1932. Stream flow from rainfall by unit-graph method. Eng. News Record 108:501-505.

Skahill, B., J. Baggett, S. Frankenstein, and C. W. Downer. 2009. More efficient PEST compatible model independent model calibration. Environmental Modelling \& Software 24(4): 517-529. doi:10.1016/j.envsoft.2008.09.011

Szilagyi, J. 2007. Analysis of the nonlinearity in the hillslope runoff response to precipitation through numerical modeling. Journal of Hydrol. 337(3-4):391401.

U.S. Army Corps of Engineers (USACE). 1959. Flood-hydrograph analyses and computations: engineering and design. EM 1110-2-1405. Washington, DC. 
USACE. 1991. Inflow design floods for dams and reservoirs. ER 1110-8-2 (FR). Washington, DC.

USACE, Baltimore District (NAB). 1963. Unit hydrographs, part I, principles and determinations. USACE NAB.

U.S. Department of Commerce (USDoC). 1978. Probable maximum precipitation estimates, United States east of the 105th meridian. Hydrometeorological Report No. 51. Washington, DC: U.S. Department of Commerce, National Oceanic and Atmospheric Administration, U.S. Department of the Army, Corps of Engineers. http://www.nws.noaa.gov/oh/hdsc/PMP_documents/HMR51.pdf.

Wolock, D., T. Winter, and G. McMahon. 2004. Delineation and evaluation of hydrologiclandscape regions in the United States using geographic information system tools and multivariate statistical analyses. Environmental Management

34(Suppl 1):S71-78. doi:10.1007/so0267-003-5077-9. 


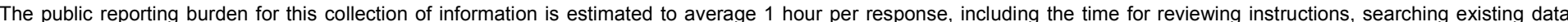

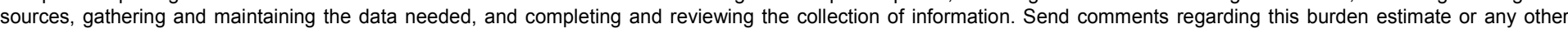

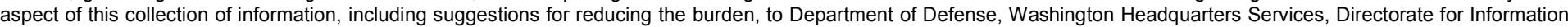

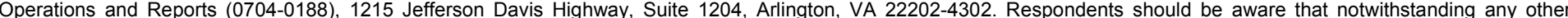
provision of law, no person shall be subject to any penalty for failing to comply with a collection of information if it does not display a currently valid OMB control number. PLEASE DO NOT RETURN YOUR FORM TO THE ABOVE ADDRESS.

\begin{tabular}{l|l|l}
\hline $\begin{array}{l}\text { 1. REPORT DATE } \\
\text { May } 2017\end{array}$ & $\begin{array}{l}\text { 2. REPORT TYPE } \\
\text { Final Report }\end{array}$ & 3. DATES COVERED (From - To) \\
\hline
\end{tabular}

\section{TITLE AND SUBTITLE}

Unit Hydrograph Peaking Analysis for Goose Creek Watershed in Virginia: A Case Study

\section{AUTHOR(S)}

7.

Nawa Raj Pradhan and Drew Loney 5a. CONTRACT NUMBER

5b. GRANT NUMBER

5c. PROGRAM ELEMENT NUMBER

5d. PROJECT NUMBER

52L3J9

5e. TASK NUMBER

5f. WORK UNIT NUMBER

8. PERFORMING ORGANIZATION REPORT NUMBER

ERDC/CHL TR-17-6

10. SPONSOR/MONITOR'S ACRONYM(S) HQUSACE

11. SPONSOR/MONITOR'S REPORT NUMBER(S)

\section{DISTRIBUTION/AVAILABILITY STATEMENT}

Approved for public release; distribution is unlimited.

\section{SUPPLEMENTARY NOTES}

\section{ABSTRACT}

Existing U.S. Army Corps of Engineers (USACE) policy suggests unit hydrograph peaking factor (UHPF), the ratio of an observed event unit hydrograph peak to the modeled one for a catchment, ranges between 1.25 and 1.50 to ensure dam safety. It is pertinent to investigate the impact of extreme flood events on the validity of this range through physically based rainfall-runoff models not available during the planning and design of most USACE dams. The UHPF range was analyzed by deploying the Gridded Surface Subsurface Hydrologic Analysis model in the Goose Creek, VA, watershed to develop a peaking factor relationship with excess rainfall for National Oceanic and Atmospheric Administration rainfall depths across various return-period events as well as the National Weather Service probable maximum precipitation event. The effect of statistical uncertainty on UHPF at Goose Creek was determined by applying the 5\% and 95\% confidence interval precipitation depths to the watershed in addition to the $50 \%$ value. This study concluded that a design event with a return period greater than 5 -year is required for the unit hydrograph to ensure dam safety. Goose Creek unit hydrograph was designed from 25 -year return period rainfall and therefore ensures dam safety given the current UHPF guidance.

\section{SUBJECT TERMS}

Floods, Flood control, Hydrologic models, Precipitation (Meteorology), Runoff, Unit Hydrograph, Watersheds--Virginia

\begin{tabular}{|l|c|c|c|}
\hline 16. SECURITY CLASSIFICATION OF: & 17. LIMITATION OF \\
a. REPORT & b. ABSTRACT & c. THIS PAGE & \\
Anclassified & Unclassified & Unclassified & SAR \\
& & & \\
\hline
\end{tabular}
18. NUMBER OF
PAGES

32 19a. NAME OF RESPONSIBLE PERSON Nawa Pradhan

19b. TELEPHONE NUMBER (Include area code) 601-634-3837 